\title{
PENERAPAN PEMBIAYAAN MURABAHAH PADA KANTOR KAS BMT DANA BAROKAH MUNTILAN KABUPATEN MAGELANG
}

\author{
Dian Junitasari \\ Akuntansi, Ekonomi, Universitas Tidar \\ Dianj0036@gmail.com \\ Risma Wira Bharata \\ Akuntansi, Ekonomi, Univrsitas Tidar \\ rismawirab@untidar.ac.id
}

Diterima: Juli 2020 Dirvisi: Oktober 2020 Diterbitkan: November 2020

\begin{abstract}
The purpose of this research is to understand the procedure for murabahah financing and the implementation of murabahah financing at BMT Dana Barokah. In conducting this research the authors chose the subjects at the cash office of BMT Dana Barokah Muntilan. This study used a qualitative method by conducting direct interviews with customers and BMT employees. The results of the study that the researchers got were the procedures for proposing murabahah financing through three stages, namely fulfilling the requirements as an applicant, then the financing coordinator collects the files submitted by the applicant to carry out a survey, then the financing coordinator analyzes the results of the survey of prospective customers if feasible then disbursement funds Goods traded by BMT, namely halal goods and goods needed by customers, are then paid for with money, goods that are traded according to customer needs must be owned by the seller and able to deliver to the buyer Payment can be made in installments or in
\end{abstract}


cash at maturity in accordance with the final agreement made by the BMT and approved by the customer.

Keywords: Murabahah financing, BMT

\begin{abstract}
Abstrak
Tujuan dari penelitian ini yaitu untuk memahami tatacara pembiayaan murabahah serta penerapan pembiayaan murabahah pada BMT Dana Barokah. Dalam melakukan penelitian ini penulis memilih subyek pada kantor kas BMT Dana Barokah Muntilan. Penelitian ini menggunakan metode kualitatif dengan cara melakukan wawancara langsung dengan para nasabah serta karyawan BMT. Hasil studi yang peneliti dapatkan yaitu procedure dalam pengajuan pembiayaan murabahah melalui tiga tahap yaitu memenuhi persyaratan sebagai pemohon, selanjutnya koordinator pembiayaan mengumpulkan berkas yang diajukan oleh pemohon berfungsi untuk melakukan survey, kemudian koordinator pembiayaan melakukan analisa dari hasil survey terhadap calon nasabah jika layak kemudian dilakukan pencairan dana Barang yang diperjualbelikan oleh BMT yaitu barang halal dan barang yang dibutuhkan oleh nasabah kemudian dibayar dengan uang, barang yang diperjualbelikan sesuai kebutuhan nasabah harus dimiliki penjual dan mampu menyerahkan kepada pembeli. Pembayaran dapat dilakukan dengan angsuran atau tunai dengan jatuh tempo sesuai dengan kesepakatan yang telak dibuat oleh pihak BMT dan disetujui oleh nasabah.
\end{abstract}

Kata kunci : Pembiayaan murabahah, BMT

\title{
A. Latar Belakang
}

Undang-undang yang menjelaskan tentang perbankan syariah dan dikeluarkan oleh Bank Indonesia merupakan peraturan dunia perbankan yang paling terbaru. Undang-undang tersebut yaitu undang-undang no. 21 tahun 2008 merupakan landasan hukum yang jelas dari segi kelembagaan dan kegiatan operasionalnya. Berdasarkan undang-undang tersebut prinsip hukum Islam yang telah diatur dalam fatwa MUI merupakan dasar bank melakukan kegiatan usahanya yaitu bank syariah. Bank syariah memiliki tugas yaitu menerima dana infaq, zakat, hibah beserta dana sosial yang 
lain sesuai dengan yang diberikan oleh UU perbankan syariah. Masyarakat memiliki peluang dalam memperoleh pelayanan perbankan berdasarkan prinsip hukum Islam yang ada didalam UU perbankan syariah. Transaksi yang tidak dilandaskan dengan bunga, dapat melayani masyarakat dengan baik dengan memenuhi kebutuhan yang sesuai dengan syariat Islam itu merupakan point lebih dari perbankan syariah ${ }^{1}$.

Baitul Maal Wat Tamwil merupakan Salah satu lembaga keuangan berlandaskan prinsip hukum Islam yang sering disebut dengan BMT. Baitul Maal Wat Tamwil yaitu lembaga keuangan mikro yang bersifat informal dan pengoperasiannya sesuai dengan prinsip bagi hasil dan memiliki fungsi untuk mengembangkan usaha mikro menengah kebawah agar dapat mengangkat derajat serta mertabat dan membela kepentingan umum masyarakat. Tanggung jawab BMT sendiri dipegang oleh departemen koperasi dan usaha menengah kebawah dan berdasarkan asas kekeluargaan serta dikelola bersama dan bersifat transparan. Fungsi utama dari BMT yaitu menghimpun dana serta menyalurkan dana masyarakat. Menyalurkan dana masyarakat yaitu memberikan pinjaman atau pembiayaan kepada masyarakat yang membutuhkan dengan prinsip bagi hasil. Menghimpun dana masayarakat yaitu dengan deposito, giro, tabungan serta bentuk simpanan yang lainnya².

Muntilan memiliki salah satu lembaga keuangan syariah yang sudah berbadan hukum yaitu BMT Dana Barokah. BMT Dana Barokah merupakan salah satu kantor kas yang berdiri dari tahun 2007 hingga sekarang. Ada beberapa produk pembiayaan yang ada didalam BMT tersebut diantaranya adalah mudharabah, musyarakah, murabahah, Bai'u Bitsaman Ajil dan Ijarah. Berdasarkan wawancara yang penulis lakukan dengan Mikdat Musa Mubaroq, S.Hi selaku koordinator

${ }^{1}$ Muhammad Yusuf, 'Analisis Penerapan Pembiayaan Murabahah Berdasarkan Pesanan Dan Tanpa Pesanan Serta Kesesuaian Dengan PSAK 102', Binus Business Review, 4.1 (2013), 15 <https://doi.org/10.21512/bbr. v4i1.1032>.

${ }^{2}$ Andreani Hanjani and Dita Ari Haryati, 'Mekanisme Pembiayaan Murabahah Pada Nasabah Di Baitul Maal Wa Tamwil Universitas Muhammadiyah Yogyakarta', Jati: Jurnal Akuntansi Terapan Indonesia, 1.1 (2018), 46-51 <https://doi.org/10.18196/jati.010105>. 
landing. Pembiayaan murabahah merupakan produk penyaluran dana yang sangat digemari oleh nasabah BMT. Transaksi jual beli barang yang menggunakan prinsip bagi hasil dengan persetujuan antara penjual dan pembeli disebut pembiayaan murabahah. Produk pembiayaan murabahah ada pada kantor kas BMT Dana Barokah adalah produk pembiayaan yang paling diminati sehingga banyak nasabahnya sekitar 60\% dari semua nasabah BMT tersebut ${ }^{3}$.

Pembiayaan murabahah merupakan salah satu pembiayaan yang paling banyak disukai oleh nasabah karena bersifat profitable dan sangat mudah dalam penerapannya. Dalam penerapan pembiayaan murabahah BMT memiliki peran sebagai pembeli dan penjual barang halal yang dibutuhkan oleh para nasabah. BMT membeli barang sesuai dengan kebutuhan nasabah kemudian barang tersebut dijual kembali kepada nasabah dengan harga pokok dan ditambah bagi hasil sesuai kesepakatan antara penjual dan pembeli yang terjadi diawal.

Penelitian ini sangat penting karena jenis pembiayaan yang paling diminati oleh sebab itu harus mengetahui penerapan pembiayaan murabahah tersebut sudah sesuai dengan aturan prinsip syariah yang ditetapkan atau belum dan juga untuk mengetahui prosedur ketika akan melakukan pengajuan pembiayaan murabahah pada BMT Dana Barokah. Penulis memilih BMT Dana Barokah sebagai tempat penelitian karena di daerah muntilan BMT tersebut sangat diminati oleh masyarakat karena tempatnya yang strategis menjadikan nasabah sangat mudah untuk mendatanginya.

Dalam melakukan penelitian ini penulis menggunakan dua metode yaitu studi lapangan dan studi perpustakaan. Dalam melakukan studi lapangan yaitu penulis melakukan peninjauan langsung ke objek penelitian dengan melakukan wawancara langsung dengan pihak-pihak yang berkaitan dengan penelitian ini. Studi perpustakaan dalam menyusun artikel ilmiah ini penulis mencari referensi dari buku ilmiah dan juga tulisan yang berkaitan dengan penelitian ini. Kemudian dalam menganalisa data yang didapatkan

\footnotetext{
${ }^{3}$ Mikdat Musa Mubarok, 'Wawancara Pribadi' (Muntilan, 2020).
} 
dari penelitian penulis menggunakan metode kualitatif dengan menjelaskan secara deskriptif mengenai penerapan pembiayaan murabahah yang diterapkan pada BMT Dana Barokah Muntilan.

Penelitian ini memiliki persamaan dengan penelitian sebelumnya yang dilakukan oleh Mila Alfiani yaitu menggunakan variable pembiayaan murabahah yang mencakup penerapan pembiayaan murabahah serta penelitiannya yang bersifat kualitatif. Perbedaan penelitian ini dengan penelitian sebelumnya yaitu metode penelitian yang digunakan dalam penelitian ini studi lapangan dan studi perpustakaan. Kemudian pada penelitian sebelumnya metode penelitiannya menggunakan teknik keabsahan data menggunakan triangulasi. Selain itu Mila Alfiani melakukan penelitian pada tahun 2018 dengan objek penelitian Manager KSU BMT Aman Utama dan anggota pembiayaan murabahah di KSU BMT Aman Utama sedangkan penelitian ini dilakukan pada tahun 2020 dengan objek penelitian Karyawan BMT Dana Barokah dan Nasabah BMT Dana Barokah.

Hasil penelitian dapat berkontribusi terhadap teori pembiayaan murabahah. Dalam penerapan pembiayaan dalam perbankan syariah agar menggunakan akad pembiayaan yang sesuai dengan kebutuhan dan juga sesuai dengan peraturan yang berlaku pada fatwa DSN MUI. Sehingga dengan begitu tidak ada lagi inkonsistensi atau ketidak selarasan anatar perilaku sesungguhnya dengan peraturan yang sudah ditetapkan.

\section{B. Hasil dan Pembahasan}

\section{Baitul Maal wat Tamwil (BMT)}

Baitul Maal wat Tamwil mencakup dua unsur kata yang pertama "bait" yang memiliki arti rumah kemudian "At Tamwil" yang berarti pengembangan harta. Baitul Maal Wat Tamwil merupakan lembaga keuangan mikro yang pengoperasiannya dengan prinsip bagi hasil bertujuan untuk mengembangkan usaha mikro menengah dan kecil supaya bisa mengangkat derajad dan membela kaum marginal. Baitul Maal wat Tamwil adalah lembaga keuangan mikro 
yang bersifat informal yang dioperasikan dengan prinsip bagi hasil untuk menumbuh kembangkan usaha mikro dan kecil agar dapat mengangkat derajad mertabat serta membela kaum marginal. Baitul Maal wat Tamwil memiliki sifat informal ${ }^{4}$.

Visi dari BMT yaitu berguna untuk membuktikan kualitas masyarakat sekitar BMT selamat, damai, sejahtera dengan usaha yang lebih maju serta berkembang, terpercaya, aman, nyaman transparan dan berkehati-hatian bersama BMT. Kemudian Misi BMT yaitu mengembangkan BMT yang maju, aman, nyaman, terpercaya, berkembang, transparan dan berkehati-hatian sehingga dapat terbukti kualitas masyarakat di sekitar BMT yang selamat damai dan sejahtera. Dalam melakukan kegiatannya BMT memiliki beberapa prinsip yaitu prinsip bagi hasil, prinsip jual beli dengan keuntungan kemudian sistem profit lainnya ${ }^{5}$.

\section{Murabahah}

Salah satu kontrak yang umum diterapkan di dalam kegiatan perbankan syariah disebut dengan murabahah. Penerapan murabahah dengan mekanisme jual beli barang dengan penambahan bagi hasil sebagai keuntungan yang didapatkan oleh BMT. Dari bermacam-macam jenis pembiayaan syariah yang ada di Indonesia pembiayaan dengan akad murabahah yaitu pembiayaan yang paling besar kontribusinya. Pada mulanya murabahah ini tidak ada hubungannya dengan prmbiayaan. Kemudian menurut para ahli dan ulama perbankan syariah memodifikasi konsep murabahah dengan beberapa konsep lain yang kemudian membentuk konsep pembiayaan dengan akad murabahah. ${ }^{6}$

Dalam pembiayaan murabahah BMT berperan sebagai pihak penjual kedua. Dalam transaksi pembiayaan murabahah terdapat risiko-risiko yaitu yang pertama bisa terjadi kegagalan BMT dalam memperoleh barang yang sesuai dengan harapan nasabah. Yang

${ }^{4}$ perbankan syariah, 'Baitul Maal Wat Tamwil', Bank Syariah, 2020 <www.syariahbank.com> [accessed 13 February 2020].

${ }^{5}$ perbankan syariah.

6 Otoritas Jasa Keuangan, 'Standar Produk Perbankan Syariah', Otoritas Jasa Keuangan, 2020 <www.ojk.co.id> [accessed 5 March 2020]. 
kedua bisa jadi BMT memperoleh barang yang cacat dari penjualnya. Yang ketiga bisa jadi nasabah berubah pikiran dan membatalkan pembelian dari barang yang telah dipesan.

Dalam penerapan pembiayaan murabahah dapat dipergunakan sebagai pembelian barang konsumsi seperti pengadaan kendaraan bermotor, pembelian rumah dan tempat tinggal lainnya selain itu juga pemenuhan kebutuhan rumah tangga lain yang diminta oleh nasabah. Untuk memenuhi kebutuhan produktif seperti untuk modal usaha dan membeli barang investasi pembiayaan murabahah juga dapat dijadikan sebagai pilihan oleh nasabah.

Untuk melaksanakan setiap aktivitas perbankan syariah membutuhkan kerangka standar operasional produk yang sesuai dengan standar syariah serta bersifat menyeluruh yang sesuai dengan prinsip syariah sehingga dapat berguna untuk meminimalisir resiko produk Murabahah. ${ }^{7}$

\section{Prinsip pembiayaan Murabahah.}

Dalam melangsungkan aktivitas pembiayaan murabahah pihak BMT harus menerapkan prinsip sebagai berikut:

a. Pembiayaan Murabahah berfungsi untuk membantu masyarakat yang membutuhkan untuk memenuhi kebutuhan konsumtif yaitu seperti pembelian rumah, alat rumah tangga dan juga kendaraan bermotor. Kemudian bisa juga untuk memenuhi kebutuhan produktif yaitu seperti investasi atau modal kerja.

b. Sebelum pembiayaan murabahah diberikan oleh BMT harus ada perjanjian yang dibuat secara tertulis antara pihak BMT dan juga nasabah sebagai bukti telah terjadi akad pembiayaan murabahah.

c. Ketika menyusun pembiayaan murabahah, BMT yang berperan sebagai penjual harus memberikan semua informasi yang berhubungan dengan objek pembiayaan kepada nasabah yang berperan sebagai pembeli yaitu seperti harga pokok

\footnotetext{
${ }^{7}$ Otoritas Jasa Keuangan.
} 
barang, margin bagi hasil, kualitas barang serta kuantitas obyek atas pembiayaan tersebut.

d. Didalam akad perjanjian pembiayaan murabahah harus terperinci secara detail bahwa BMT menjual barang kepada nasabah dengan harga jual yang mencakup harga perolehan dari barang dan persentasi margin bagi hasil.

e. Harga perolehan mencakup sejumlah dana yang dikeluarkan oleh BMT untuk memiliki barang tersebut ditambah dengan biaya yang berhubungan langsung dengan pengadaan barang dan harus dinyatakan secara detail dan transparan oleh pihak BMT kepada nasabah.

f. Biaya-biaya yang berhubungan langsung yang kemudian diperhitungkan dalam penetapan harga yaitu seperti biaya pengiriman barang dan juga biaya pemeliharaan maupun peningkatan nilai barang seperti pembuatan surat-surat barang.

g. Nasabah yang berperan sebagai pembeli berjanji untuk membayar harga yang sudah disetujui atas objek pembiayaan dengan cara kredit maupun tunai dengan pihak BMT pada jangka waktu tertentu sesuai dengan kesepakatan pada kontrak perjanjian ${ }^{8}$.

\section{Landasan Syariah Murabahah}

a. Menurut Al Qur'an

Jual beli menurut Islam hukumnya diperbolehkan dengan syarat berdasarkan dalil dari Al Qur'an, ijma' dan sunnah. Berikut dalil Al-Qur'an adalah firman Allah : "Dan Allah telah menghalalkan jual beli dan mengharamkan riba" (QS. Al-Baqarah: 275). "Dan persaksikanlah apabila kamu berjual beli" (QS. Al-Baqarah 282), dan "Tidak ada dosa bagimu untuk mencari karunia (rezeki hasil perniagaan) dari Tuhanmu" (QS. Al-Baqarah 198) .

b. Menurut Hadits

\footnotetext{
${ }^{8}$ Otoritas Jasa Keuangan.

9 'Surah Al Baqoroh', in Al Qur'an, p. 198.
} 
Menurut Islam, perniagaan dan perdagangan selalu dikaitkan dengan nilai-nilai moral, sehingga transaksi yang bertolak belakang dengan kebajikan tidak bersifat islami. Contohnya yaitu penjual harus memberikan informasi kepada pembeli mengenai kondisi barang seperti apapun keadaan barang misalnya layak pakai serta tidak ada cacat dan ketika cacatpun harus disampaikan secara jelas. Dalam hadist disebutkan sebagai berikut : "Pembeli dan penjual berhak untuk membatalkan perjanjian mereka selama mereka tidak terpisah. Apabila mereka itu berbicara benar dan menjalankannya, maka transaksi itu akan diberkahi, tetapi bila mereka saling menyembunyikan dan berdusta, maka berkah atas transaksi mereka itu akan pupus" (HR Bukhari).

Dari Suhaib ar-Rumi r.a. bahwa Rasulullah saw. Bersabda: "Tiga hal yang di dalamnya terdapat keberkahan: jual beli secara tangguh, muqaradhah (mudharabah), dan mencampur gandum dengan tepung untuk keperluan rumah, bukan untuk dijual" (HR Ibnu Majah) ${ }^{10}$.

Kaitan landasan syariah tentang murabahah dengan penelitian ini yaitu sebagai landasan bahwa pembiayaan murabahah yang dilakukan tertulis dalam hadits dan AlQur'an sebagaimana dijelaskan diatas. Dan dijadikan acuan dalam melakukan kegiatan jual beli.

\section{Pembiayaan Murabahah Menurut Fatwa DSN MUI}

Menurut ketentuan Fatwa DSN No 04/DSN-MUI/IV/2000 tentang murabahah terdapat ketentuan sebagai berikut :

1) Ketentuan umum murabahah kepada bank menurut ketentuan Fatwa DSN No 04/DSN-MUI/IV/2000 adalah sebagai berikut:

a. Bank dan nasabah harus melakukan akad murabahah yang bebas riba.

${ }_{10}$ Mila Alfiani, Aan Zainul Anwar, and Darwanto Darwanto, 'Analisis Pembiayaan Murabahah Pada BMT', Jesya (Jurnal Ekonomi E Ekonomi Syariah), 1.2 (2018), 69-80 <https:/ / doi.org/10.36778/jesya.v1i2.10>. 
b. Barang yang diperjualbelikan harus halal.

c. Bank membiayai sebagian atau seluruh harga pembelian barang yang telah disepakati.

d. Bank membeli barang yang diperlukan oleh nasabah atas nama bank sendiri dan pembelian ini harus sah dan bebas riba.

e. Bank harus menyampaikan semua hal yang berkaitan dengan pembelian barang.

f. Bank kemudian menjual barang kepada nasabah dengan harga jual senilai harga beli ditambah dengan keuntungannya.

g. Nasabah membayar harga barang yang telah disepakati tersebut pada jangka waktu tertentu yang telah disepakati.

h. Untuk mencegah terjadinya penyalahgunaan atau kerusakan akad tersebut, bank dapat mengadakan perjanjian khusus dengan nasabah.

i. Ketika bank akan mewakilkan kepada nasabah untuk membeli barang dari pihak ketiga, akad jual beli murabahah harus dilakukan setelah barang, secara prinsip menjadi milik bank. ${ }^{11}$

2) Ketentuan umum murabahah kepada nasabah menurut ketentuan Fatwa DSN No 04/DSN-MUI/IV/2000 adalah sebagai berikut :

a. Nasabah melakukan permohonan dan janji pembelian suatu barang atau asset kepada bank.

b. Jika bank menerima pemohonan tersebut, ia harus membeli terlebih dahulu asset yang dipesannya secara sah dengan pedagang.

c. Bank kemudian menawarkan asset tersebut kepada nasabah dan nasabah harus menerimanya sesuai perjanjian yang telah disepakatinya.

${ }^{11}$ Fatwa DSN-MUI, tentang akad murabahah, www.DSN-MUI. or.id , 8 Maret 2020 
d. Dalam kegiatan jual beli ini bank diperbolehkan meminta nasabah untuk membayar uang muka saat menandatangani kesepakatan awal pemesanan.

e. Jika nasabah kemudian menolak membeli barang tersebut, biaya riil bank harus dibayar dengan uang muka tersebut.

f. Jika nilai uang muka kurang dari kerugian yang harus ditanggung oleh bank, bank dapat meminta kembali sisa kerugiannya kepada nasabah.

g. Jika uang muka memakai kontrak uang muka, maka:

(a) jika nasabah memutuskan untuk membeli barang tersebut, nasabah tinggal membayar sisa harga.

(b) jika nasabah batal membeli, uang muka menjadi milik bank maksimal sebesar kerugian yang ditanggung oleh bank akibat pembatalan tersebut, dan jika uang muka tidak mencukupi, nasabah wajib melunasi kekurangannya. ${ }^{12}$

\section{Skema Akad Murabahah}

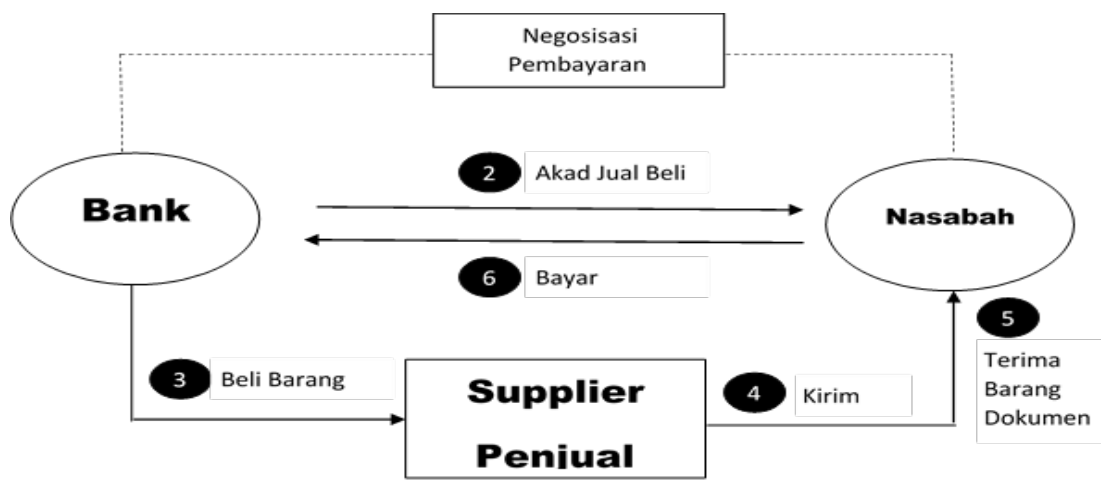

Dari sSkema diatas dapat dijelaskan proses pembiayaan murabahah sebagai berikut:

a. Negoisasi dan persyaratan

Nasabah melakukan penawaran ataupun negosiasi dengan pihak BMT yang berkaitan dengan kondisi fisik barang diharapkan oleh nasabah, penawaran harga jual serta harga

${ }^{12}$ Fatwa DSN-MUI, tentang akad murabahah, www.DSN-MUI. or.id , 8 Maret 2020 
beli, kemudian jangka waktu dalam pelunasan dan beberapa persyaratan yang harus dipenuhi oleh nasabah berdasarkan peraturan yang berlaku pada bank syariah.

b. Pihak BMT membeli barang kepada supplier sesuai dengan kesepakatan yang dilakukan dengan nasabah.

c. Akad jual beli

Kemudian setelah pihak BMT membelikan barang berdasarkan kebutuhan nasabah kepada supplier selanjutnya pihak BMT menjualnya kembali kepada nasabah dengan proses penandatanganan akad jual beli antara BMT dengan nasabah, pada kesepakatan tersebut pihak BMT menjelaskan hal-hal yang berkaitan dengan jual beli murabahah, rukun kemudian syarat-syarat yang harus dipenuhi dalam pembiayaan tersebut.

d. Langkah selanjutnya supplier mengirimkan barang yang dibeli oleh pihak BMT ke alamat nasabah yang tertera pada akad perjanjian yang telah disepakati antara pihak BMT dan nasabah.

e. Kemudian tanda terima produk barang yang dibeli beserta dokumen, ketika barang sudah samapai ke alamat nasabah, sehingga nasabah harus menandatangani surat tanda terima barang tersebut serta mengecek kembali kelengkapan dokumen dari barang tersebut. Selanjutnya nasabah membayar harga barang yang dibeli dari BMT, biasanya pembayaran dilakukan secara kredit dalam jangka waktu tertentu sesuai dengan kesepakatan sebelumnya.

\section{Prosedur Pembiayaan Murabahah}

Dalam penyaluran pembiayaan ada beberapa aktivitas yang harus dilakukan dalam pembiayaan murabahah. Procedure yang harus dilakukan yaitu sebagai berikut :

a. Nasabah melakukan pengajuan permohonan pembiayaan.

Dalam pengajuan pembiayaan murabahah pada BMT Dana Barokah calon nasabah harus melengkapi beberapa 
persyaratan. Terdapat dua persyaratan yaitu secara khusus dan umum.

Persyaratan secara umum sebagai berikut :

1. calon nasabah bersedia menjadi anggota BMT Dana Barokah

2. Bersedia membuka rekening tabungan wadi'ah

Persyaratan secara khusus sebagai berikut :

1. Mengisi formulir pembiayaan yang disediakan oleh BMT.

2. Fotocopy KTP (Kartu Tanda Penduduk) Suami Istri.

3. Fotocopy KK (Kartu Keluarga).

4. Fotocopy Rekening tabungan.

5. Fotocopy Jaminan jika rumah yaitu sertifikat beserta kartu PBB maupun jika kendaraan yaitu dengan BPKB dan STNK.

b. Pemeriksaan kelengkapan administrasi yang dilakukan oleh pihak BMT.

Formulir beserta syarat-syarat yang dilakukan oleh nasabah akan diperiksa oleh pihak BMT, untuk memeriksa kelengkapan administrasi. Ketika persyaratan sudah lengkap kemudian bagian administrasi akan menyerahkan ke Account Officer untuk melakukan survey jaminan yang diajukan.

c. Pelaksanaan survey yang dilakukan oleh Account Officer.

AO setelah melakukan survey untuk mendapatkan data-data yang dibutuhkan. Survey dilakukan paling lama 3 hari setelah pengajuan permohonan. Survey dilakukan oleh Account Officer atau kepala cabang. Survey dilakukan bertujuan untuk mendapatkan data calon nasabah tentang jaminan pembiayaannya.

d. Pembuatan nota yang dilakukan oleh Teller.

Setelah melakukan survey maka data yang didapatkan dari sesudah dan sebelum survey, maka koordinator bagian pembiayaan akan menganalisis terhadap kelayakan calon nasabah pembiayaan. 
Analisa tersebut adalah sebagai berikut :

1. Karakter pemohon

Sifat calon nasabah berupa kejujuran, perilaku dan ketaatannya. Untuk mendapatkan informasi tersebut yaitu dengan menanyakan dengan tetangganya dan dari bank lain yang telah memberikan pembiayaan kepada calon nasabah sebelum mengajukan pembiayaan ke BMT Dana Barokah.

2. Kemampuan

Analisa yang dilakukan pada kemampuan pengembalian pembiayaan nasabah ke BMT Dana Barokah.

3. Agunan

Kemampuan calon nasabah dalam memberikan jaminan yang layak sesuai dengan nilai nominal pembiayaan. Jaminan berperan sangat penting apabila mengalami kemacetan dalam melunasi BMT tidak mengalami kerugian karena dapat di tutup dengan penjualan jaminan tersebut.

e. Keputusan pembiayaan yang dilakukan rapat yang diselenggarakan oleh Kepala Cabang.

Dalam memutuskan pemberian pembiayaan kepada calon nasabah biasanya kepala cabang akan melakukan rapat dalam memutuskan layak tidaknya nasabah yang akan diberikan pinjaman.

Jika layak maka calon nasabah akan ditelfon untuk datang ke kantor dan diberikan surat persetujuan yang dibuat oleh BMT dan ditanda tangan oleh nasabah. Namun apabila BMT tidak memberikan persetujuan dalam artian jaminan tidak layak maka nasabah akan diberitahukan melalui telfon.

f. Penandatanganan Akad pembiayaan

Jika calon nasabah sepakat dengan surat putusan yang berisi peraturan dalam pembiayaan tersebut maka proses berikutnya adalah melakukan tanda tangan akad pembiayaan yang dihadiri juga oleh notaris.

g. Pencairan dana. 
Setelah melakukan penandatangan akad pembiayaan maka nasabah bisa mengambil dana dari BMT Dana Barokah.

Adapun beberapa kelengkapan administrasi yang harus ada dalam pembiayaan ini :

1) Dokumen pembiayaan

Beberapa dokumen yang diperlukan oleh BMT Dana Barokah adalah sebagai berikut :

1. Surat pemberitahuan permohonan.

2. Akad murabahah dengan notaris.

3. Pengikatan jaminan berupa fidusia, gadai dan Surat Kuasa Memegang Hak Tanggungan.

4. Surat perintah realisasi pembiayaan.

5. Surat tanda terima pembiayaan.

6. Surat izin penyitaan jaminan jika terjadi penunggaan secara berturut-turut dalam jangka waktu tiga bulan lebih.

2) Jaminan pembiayaan

Pembiayaan yang diberikan oleh BMT Dana Barokah terdapat resiko suatu hal yang tidak diinginkan. Untuk meminimalisir resiko tersebut maka BMT mensyaratkan jaminan dalam pembiayaan sebagai bukti keseriusan nasabah dalam pinjaman yang digunakan atas kesanggupan nasabah untuk mengembalikan sesuai dengan kesepakatan.

Jaminan dari nasabah yang diberikan untuk BMT sebagai jaminan suatu pinjaman harus dinilai terlebih dahulu agar mengetahui nilai ekonomis dari jaminan tersebut. Disamping nilai ekonomis juga harus dilihat kepemilikan jaminan tersebut. Jika dengan nama lain tidak sesuai dengan pemohon harus menggunakan surat kuasa bukti bahwa yang bersangkutan menyetujuinya jika dipindahkan penguasaanya sebagai jaminan 
pinjaman. Barang yang dapat dijadikan pinjaman adalah sebagai berikut :

1. Rumah dalam bentuk Sertifikat Hak Milik

2. Kendaraan dalam bentuk BPKB.

3) Asuransi

Untuk menghindari resiko BMT mengalami kerugian ketika nasabah mengalami kemacetan dalam melunasi kewajiban utangnya atau terjadi hal yang tidak diinginkan dengan mengurangi nilai ekonomis atau bahkan habis, maka BMT Dana Barokah mengikutsertakan nasabah dalam program asuransi. Ketika suatu waktu nasabah memang sudah tidak dapat melunasi maka pembiayaan tersebut akan di back-up oleh perusahaan asuransi dan kemudian premi akan ditanggung oleh nasabah.

\section{Persepsi nasabah BMT Dana Barokah beserta karyawan terhadap Pembiayaan Murabahah}

Berdasarkan penelitian yang penulis lakukan dengan metode wawancara untuk mengetahui penerapan pembiayaan murabahah yang terjadi pada BMT Dana Barokah. Dalam melakukan pengajuan pembiayaan murabahah terdapat beberapa syarat yaitu syarat umum dan syarat khusus. Syarat umum pembiayaan tersebut adalah pemohon bersedia menjadi anggota BMT kemudian pemohon bersedia mengisi formulir pengajuan pembiayaan murabahah yang disediakan oleh pihak BMT. Secara khusus terdapat syarat sebagai berikut yang pertama, pemohon mengumpulkan fotocopy KTP,KK, buku nikah jika sudah menikah dan juga fotocopy jaminan seperti BPKB dan STNK atau Sertifikat dan kartu PBB sebanyak 2 lembar.

BMT dalam melakukan kesepakatan pembiayaan murabahah tersebut meminta jaminan kepada pemohon pembiayaan. Fungsinya adalah sebagai bukti keseriusan pemohon pembiayaan kepada BMT. Hal tersebut dilakukan agar mengurangi resiko orang-orang yang tidak bertanggung jawab dengan mengingkari akad yang sudah dibuat tanpa melunasinya. Dengan jaminan tersebut jadi orang yang 
akan melakukan tindakan kecurangan akan berpikir dua kali atau jaminan tersebut akan hangus.

Barang yang diperjualbelikan oleh BMT juga merupakan barang yang halal sesuai dengan syariat islam. Sesuai dengan ketetapan OJK dan Fatwa DSN MUI bahwa dalam pembiayaan murabahah barang yang diperjualbelikan merupakan barangbarang untuk memenuhi kebutuhan konsumtif seperti sepeda motor, mobil, handphone dan lainnya. Dalam memenuhi kebutuhan pemohon BMT akan membelikan barang atas nama BMT sendiri atau bisa juga BMT memberikan surat kuasa kepada pemohon untuk membeli sendiri tetapi dengan barang bukti harus disertai nota dari penjual barang tersebut kemudian diserahkan kepada pihak BMT. BMT akan memberitahukan secara transparan harga sesungguhnya dari barang yang diperjualbelikan dan juga menawarkan kepada pemohon apakah pemohon sepakat dengan harga tersebut jadi tidak diputuskan satu pihak saja. Dalam menentukan margin BMT Dana Barokah menawarkan margin yang diperoleh oleh BMT dan membuat kesepakatan apakah pemohon setuju dengan margin tersebut. Jika pemohon tidak sepakat akan terjadi tawar menawar agar kedua belah pihak sepakat. Kesepakatan disesuaikan dengan kemampuan pemohon dalam membayarnya. Hal tersebut dilakukan untuk menghindari kemacetan pembiayaan. Spesifikasi barang yang diperjualbelikan akan diberitahukan secara jelas oleh pihak BMT ketika akad pembelian tersebut sudah sepakat.

Menurut bapak Waryanto selaku nasabah pada BMT Dana Barokah, BMT akan membelikan apa yang dibutuhkan oleh nasabah atas nama BMT sendiri kemudian dijual kembali kepada nasabah sesuai dengan kesepakatan. Atau bisa juga BMT akan memberi surat kuasa kepada nasabah untuk membeli barang sendiri dan harus membawa barang bukti berupa nota

Persepsi nasabah terhadap prosedure pembiayaan murabahah pada BMT Dana Barokah yang diungkapkan oleh Ibu Linda selaku nasabah BMT menurutnya prosedure dalam pembiayaan murabahah mudah dan simple serta prosesnya yang tidak lama sehingga tidak 
mempersulit nasabah yang akan mengajukan pembiayaan murabahah oleh karena itu beliau tertarik dengan pembiayaan tersebut.

\section{Penerapan Pembiayaan Murabahah pada BMT Dana Barokah}

Pembiayaan murabahah merupakan produk unggulan dari BMT Dana Barokah Muntilan dengan prinsip bagi hasil tidak ada unsur riba yaitu harga sudah ditetapkan sejak awal dan harga akan tetap sama sampai akhir sesuai dengan kesepakatan. Pada kegiatan operasional pembiayaan pada KSPPS BMT Dana Barokah, sudah sesuai dengan peraturan sesuai OJK maupun Fatwa MUI yang berkaitan dengan perbankan syariah bidang pembiayaan murabahah baik dalam pengajuan pembiayaan, proses survey dan juga analisa pembiayaan.

BMT Dana Barokah dalam melaksanakan praktik murabahah sesuai dengan pesanan yang bersifat mengikat serta pembayaran bisa dilakukan dengan kredit atau angsuran atau bisa juga dengan pembayaran tangguhan dengan jatuh tempo. BMT dalam memberikan pembiayaan pembiayaan tidak sembarangan memberikan kepada calon nasabah. Namun, terdapat beberapa hal yang harus dilakukan oleh nasabah dan juga terdapat beberapa persyaratan yang dibutuhkan. Dengan mensurvey calon nasabah yang akan melakukan pengajuan pembiayaan.

Terdapat dua elemen pokok sebagai dasar dalam penerapan pembiayaan murabahah yaitu harga beli dan juga tambahan biaya keuntungan yang telah disepakati oleh nasabah dan juga pihak BMT. Pembiayaan murabahah memiliki beberapa karakteristik sebagai berikut yaitu nasabah harus mengetahui secara menyeluruh mengenai biaya-biaya yang berhubungan dengan produk yaitu mencakup biaya administrasi dan juga harga pokok barang yang sudah ditambah dengan keuntungan yang ditetapkan dari presentase total harga. Barang yang dijual yaitu barang yang halal dan barang kebutuhan nasabah yang dibayar dengan uang, barang yang diperjualbelikan sesuai kebutuhan nasabah harus dimiliki penjual dan mampu menyerahkan kepada pembeli. Pembayaran dapat dilakukan dengan 
angsuran atau tunai dengan jatuh tempo sesuai dengan kesepakatan yang telak dibuat antara pihak BMT dan Nasabah.

Persepsi Nasabah terhadap penerapan pembiayaan murabahah pada BMT Dana Barokah menurut Ibu Indah selaku nasabah BMT yang melakukan pembiayaan murabahah yaitu beliau mengatakan bahwa penerapan pembiayaan murabahah pada BMT Dana Barokah sudah memenuhi kebutuhan nasabah selain itu pembiayaan murabahah memberikan manfaat kepada nasabah yang akan melakukan pembelian barang namun belum memiliki uang yang cukup. BMT Dana Barokah telah menerapkan pembiayaan murabahah sesuai dengan prinsip yang telah ada.

Namun BMT Dana Barokah dalam menerapkan pembiayaan murabahah ada perilaku yang tidak selaras dengan peraturan yang berlaku. Perilaku tersebut yaitu masih menggunakan pembiayaan murabahah untuk modal usaha atau peminjaman uang hal tersebut terjadi dikarenakan banyaknya permintaan dari masyarakat yang menggunakan pembiayaan murabahah karena syarat-syarat yang tergolong mudah dan tidak ribet sehingga para nasabah memilih menggunakan pembiayaan tersebut. Solusi alternatifnya yaitu pihak BMT harus tegas dan taat terhadap peraturan yang berlaku. Pembiayaan murabahah dikhususkan untuk kegiatan jual beli. Kemudian untuk kegiatan peminjaman uang dan modal usaha bisa menggunakan akad pembiayaan lain yang fungsinya sesuai dengan kebutuhan yang dibutuhkan oleh nasabah. Sehingga dalam penerapan pembiayaan murabahah bisa selaras dengan peraturan yang berlaku.

\section{Kesimpulan}

Prosedur dalam melakukan pengajuan pembiayaan murabahah yaitu dengan dua persyaratan yang pertama secara umum dan yang kedua secara khusus. Persyaratan secara umum yaitu bersedia menjadi anggota BMT dan bersedia mengisi formulir permohonan pembiayaan. Kemudian bersyaratan secara khusus yaitu dengan memberikan fotocopy surat-surat yang dibutuhkan sebanyak 2 lembar, surat-surat tersebut terdiri dari fotocopy KTP 
yang mengajukan pembiayaan, fotocopy kartu keluarga, fotocopy buku nikah jika sudah menikah jika belum ya tidak usah kemudian fotocopy jaminan yaitu jika kendaraan bermotor BPKB dan STNK atau jika rumah menggunakan sertifikat dan SPPT atau kartu PBB. Kemudian untuk penerapan pembiayaan murabahah sudah sesuai dengan prinsip syariah yaitu diatur dalam Standar OJK dan Fatwa DSN No 04/DSN-MUI/IV/2000.

Terdapat dua elemen pokok yang mendasari dalam penerapan pembiayaan murabahah yaitu harga beli serta tambahan biaya keuntungan sesuai dengan kesepakatan pada awal. Pembiayaan murabahah memiliki beberapa karakteristik sebagai berikut yaitu nasabah harus mengetahui secara menyeluruh mengenai biayabiaya yang berhubungan dengan produk yaitu mencakup biaya administrasi dan juga harga pokok barang yang sudah ditambah dengan keuntungan yang ditetapkan dari presentase total harga. Barang yang dijual yaitu barang yang halal dan barang kebutuhan nasabah yang dibayar dengan uang, barang yang diperjualbelikan sesuai kebutuhan nasabah harus dimiliki penjual dan mampu menyerahkan kepada pembeli. Pembayaran dapat dilakukan dengan angsuran atau tunai dengan jatuh tempo sesuai dengan kesepakatan yang telak dibuat antara pihak BMT dan Nasabah.

Pada kenyataannya BMT Dana Barokah belum sepenuhnya konsisten dengan fatwa DSN MUI oleh karena itu sebaiknya BMT dalam menerapkan pembiayaan murabahah ini digunakan sesuai dengan standar yang berlaku. Dikhususkan untuk kegiatan jual beli. Ketika untuk pemenuhan kebutuhan ataupun untuk peminjaman uang sebaiknya menggunakan akad mudharabah atau musyarakah yang sesuai dengan standar yang berlaku. 


\section{DAFTAR PUSTAKA}

Alfiani, Mila, Aan Zainul Anwar, and Darwanto Darwanto, 'Analisis Pembiayaan Murabahah Pada BMT', Jesya (Jurnal Ekonomi \& Ekonomi Syariah), 1.2 (2018), 69-80 <https://doi. org/10.36778/jesya.v1i2.10>

Hanjani, Andreani, and Dita Ari Haryati, 'Mekanisme Pembiayaan Murabahah Pada Nasabah Di Baitul Maal Wa Tamwil Universitas Muhammadiyah Yogyakarta', Jati: Jurnal Akuntansi Terapan Indonesia, 1.1 (2018), 46-51 <https://doi. org/10.18196/jati.010105>

Mikdat Musa Mubarok, 'Wawancara Pribadi' (Muntilan, 2020)

Otoritas Jasa Keuangan, 'Standar Produk Perbankan Syariah', Otoritas Jasa Keuangan, 2020 <www.ojk.co.id> [accessed 5 March 2020]

perbankan syariah, 'Baitul Maal Wat Tamwil', Bank Syariah, 2020 <www.syariahbank.com> [accessed 13 February 2020]

'Surah Al Baqoroh', in Al Qur'an, p. 198

Yusuf, Muhammad, 'Analisis Penerapan Pembiayaan Murabahah Berdasarkan Pesanan Dan Tanpa Pesanan Serta Kesesuaian Dengan PSAK 102', Binus Business Review, 4.1 (2013), 15 <https://doi.org/10.21512/bbr.v4i1.1032> 
Penerapan Pembiayaan Murabahah... 